\title{
Belgeo
}

Revue belge de géographie

\section{The nature of changes in human geography since the 1980s: variation or progress?}

La nature des changements en géographie humaine depuis les années 80: variations ou progrès?

\section{Christian Kesteloot and Pieter Saey}

\section{(2) OpenEdition}

\section{Journals}

Electronic version

URL: http://journals.openedition.org/belgeo/16227

DOI: $10.4000 /$ belgeo.16227

ISSN: 2294-9135

\section{Publisher:}

National Committee of Geography of Belgium, Société Royale Belge de Géographie

Printed version

Date of publication: 30 June 2003

Number of pages: 131-144

ISSN: 1377-2368

\section{Electronic reference}

Christian Kesteloot and Pieter Saey, "The nature of changes in human geography since the 1980s: variation or progress? », Belgeo [Online], 2 | 2003, Online since 30 July 2003, connection on 19 April 2019. URL : http://journals.openedition.org/belgeo/16227 ; DOI : 10.4000/belgeo.16227

This text was automatically generated on 19 April 2019.

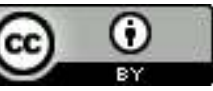

Belgeo est mis à disposition selon les termes de la licence Creative Commons Attribution 4.0 International. 


\title{
The nature of changes in human geography since the 1980s: variation or progress?
}

\author{
La nature des changements en géographie humaine depuis les années 80: \\ variations ou progrès?
}

Christian Kesteloot and Pieter Saey

1 When looking at the mainstream scientific production of human geographers in international (Anglo-Saxon) publications, there can be no doubt about shifts in geography since the 1980s. A good way to illustrate this is to show how geographers look at their production, especially if it is a production that does not fit into their own approach or paradigm.

Consider this citation:

«The journal is a clear leader in [spatial analysis], and its publications have had a significant impact within and beyond the discipline. It has also been a rallying point to preserve scientific inquiry and, to some extent, a pillar of scientific positivist research. This is meant to be a laudatory statement and carries no negative implications as would normally be the case if offered as a comment by a social theorist or postmodernist.

This strength is important..., particularly now that scientific research and technological innovation have become woven into... 'the information society'. By maintaining an emphasis on theory and methodology in the spatial analysis domain,... [the journal] has well served the discipline, and, despite an increasing vocal criticism from some nonanalytic parts of the discipline, there is no doubt... that it is the scientific methodological and analytical contributions by geographers that have increased our visibility and acceptability by other sciences.»

3 It is extracted from the review article of a former editor in the special 30th anniversary issue of «Geographical Analysis» (Golledge, 1999, pp. 321-322).

4 A second biting example concerns classical regional geography, an approach that apparently refuses to disappear: 
"One is first impressed by the volume, by the prestige of the authors and the quality of the illustration: a very nice thick book, an inexhaustible source of information, surely, no library could afford to miss it. But this makes it all the worse. Indeed, this exemplary monument has all the characteristics of a dinosaur: it is a big fossil, from a well-known species, but that was thought to be extinct.» (Brunet, 1993, reviewing Denis, 1992, a 622 pages book organised along the classical descriptive framework of Hettner or Vidal de la Blache).

But if old approaches and subjects remain, new ones also appear, as testified by the subjects in recent social and cultural geography conferences. Among others a conference in London in 2002 announces itself as follows: «The conference emerges out of increasing research and theoretical interests in the material geographies of the non-human world. This renewed geographical focus on objects/matters/things may be understood as part of a wider questioning of the dominance of textual or representational conceptions of the social world.» The subjects include «Objectivation, the Gaze and Power», «Popular Culture (music, fashion, etc.)», «Technologies and Machines», «Aesthetics and Art», «Materialities of Poverty and Power», «Social Difference and Materiality», "Agency and Objects», «Everyday Life» and Materiality», «Materialities of Nature», «Embodiment and Things», «Post-Humanism», etc.

6 The least that can be said is that geographers do not share a common view and do not work at the same development of the discipline...

\section{Factors of change}

7 The period covered by this review ${ }^{1}$ has been marked by important societal changes that largely influenced geographical practice. The deepening of the economic crisis and globalisation in the economic sphere, global change at the interface between physical and human phenomena, the disappearance of communist regimes in the political sphere and postmodernism in the cultural field, have brought new research subjects and made others appear desperately obsolete (in urban geography, factorial ecology is now replaced by studies of globalisation and polarisation, in economic geography, distance and transportation costs have given way to flexibility, networks or learning regions to name a few examples). One could also look at the institutional changes and observe how new subjects are developed through new funding sources. A good example is the development of E.U. research and how social exclusion became imposed as a pan-European research subject over the last decades (similarly, many regions and cities are pouring more money into research in order to explore their local assets and drawbacks in a global economy).

8 A second factor of change is the internal scientific debate, which necessarily interacts with these societal changes. The paradigms of the sixties and seventies suddenly appear as anachronisms, new proposals emerge, often inspired by concepts and research outside geography. But all this is mediated by the institutions of academic research. Thus, these debates are also embedded in relations between teams and networks, in access to research funding, in inter-university competition (and the wave of quality assessments and rankings), in publication policies (with an increasing commercialisation fed by the latter pressure to publish internationally), which all channel and sift the new and the old. As a result, current practice apparently cuts across the common threefold classification into classical, neo-positivist and radical approaches. It thus resurrected regional, political and cultural geography, initiated the decline of neo-positivist approaches that flourished 
in an era of planning and economic growth (explaining perhaps the blatant defence of it by Geographical Analysis) and undermined the appeal of Marxist approaches.

9 A third source of change should be added, namely technological changes that found their way into geography in the development of GIS.

Interestingly, by studying global change and stressing what they still discreetly call «anthropogenic factors» in physical phenomena, physical geography is not immune to these changes. It has gained in social relevance and could, once the interaction between nature and society is studied in both directions, reconnect with human geography on subjects like environmental and development problems (see Veyret in this issue) ${ }^{2}$.

11 In this turmoil of trends and events, human geography has grown into a fully recognised social science that contributes to the understanding of society by unravelling its spatial organisation and understanding the structuring effects of this organisation on social action. Both theoretical progress and new social, economic and political problems have made clear that social analysis without a spatial dimension cannot possibly reach the essence of present and future social reality.

\section{What is new in human geography?}

At first sight, one could speak about a «French disease» in human geography when overviewing the recent geographical production. Many of the new concepts emerging from the changes in geographical research emanate from reading French philosophical contributions. Authors like Henri Lefebvre, Michel Foucault, Bernard Latour, Jacques Lacan, Gilles Deleuze and Felix Guattari, Michel de Certeau, Jacques Derrida and JeanFrançois Lyotard all pop-up in English language geography literature. Even the writing style of this literature has changed under the French disease. It is much more wordy and fashionable than it ever was. The up-to-date geographer «discloses», «deconstructs» and «excavates», «contextualises», «reconstitutes», «embodies» and «re-conceptualises»... We call this a «disease» because of the tendency to erase, or make irrelevant, the difference between ontology and epistemology ${ }^{3}$, and the inclination to blow up psychological problems into metaphysical aspects of the human condition ${ }^{4}$.

But behind the façade of a lot of evanescent and gratuitous work, one can grasp the essence of the changes in geographical practice. We try to do it with two metaphors ${ }^{5}$, holography and ethnography and two more essential features of the novelties, institutionalism and constructivism.

\section{Holography}

14 Human geography is now holographic rather than holistic or purely analytic: in many research, the whole is described through an analysis of a part of it, which logically implies a view on reality in which the parts contain the whole. This is particularly expressed in geography through a multiscalar analysis of the subjects and an integral or integrating (multi-, inter-, transdisciplinary) approach ${ }^{6}$.

An example of the former is the analysis the distribution of immigrants. At the national level, this would yield an understanding of their economic role in their new country when compared to the regional economic geography of that country. But when jumping to the intraregional or intra-urban scale, the structure of the housing market will 
interrelate with this socio-economic position in order to explain concentration areas of the groups under consideration. Clearly both scales have to be combined in order to get a coherent picture. Even more, in many cases transnational networks have to be involved in the analysis, if one wants to understand the ethnic infrastructure, entrepreneurship and survival strategies of the immigrants involved.

Multiscalar analysis in geography has probably a long history, although the interplay between the scales is not always explicitly analysed (while the key for understanding the phenomena is precisely situated in this interplay). But monoscalar analysis has been surely much more widespread, with sometimes devastating effects ${ }^{7}$. Today multiscalar analysis is even pushed further with the emergence of debates on politics of scale (Swyngedouw, 2003). Scales are not anymore seen as fixed and given, but as products of human interaction. The international scale has changed over history with the development of the world(-)system. And what sense would it have to speak about a national scale before the emergence of the nation-states? Scales are socially produced, but control of scales are also a matter of power, hence politics of scale.

Integrating research has gradually transformed geography in a holographic approach of society. It is not difficult to find in the geographical literature of the late seventies and eighties examples of desperate circumscriptions of this aspect. The adjectives «social», «economic», "political», "cultural» are all used together to precise what spatial structures or processes are about. To a certain extent, this could be related to the exceptional character of geography that was forcefully attacked by Schaefer back in 1953 (geography as the sole science that would not be able to construct theories or that would not aim at theory construction as its primary goal). As a matter of fact, the theoretical and quantitative geography that would follow Schaefer's plea for a nomothetic conception of the discipline has brought geography away from its integrating/ holographic nature, because, as in every (neo-) positivist science, successful research is based on decomplexifying reality into separate elements and studying the relations between single elements. Especially the integral approach of Marxism and the basics of historical materialistic ontology, stating that everything is in relation with other things, gave the thrust to bring the pendulum back. However, it is not a return to holism, neither is it a return to the former position as regards content. The societal approach implied in radical geography, in particular its attention to power relations, has definitively condemned any trial to explain societal diversity by mere physical characters of territories. ${ }^{8}$. Today human geography can be fully regarded as a social science and the anxious definitions and delimitations of the geography discipline have given way to unabashed contributions to the fundamental present-day debates in social sciences.

\section{Ethnography}

The second metaphoric expression of change in human geography is ethnography. By this we mean that reality is unveiled by the analysis of everyday practice, of individual actors and events. To a certain extent, this is just a synonym for the former new character of geography. However, ethnography not only documents the idiosyncrasies of social reality. Precisely by closely observing what people do but also what they say about their activities, it discovers the symbolic order behind it. This symbolic construction is to be understood as the set of meanings that sustain and replicate the position of individuals and groups in a larger social order. Very often, these meanings and symbols are rooted in 
space, expressed in the landscape, which make them much more geographical than accepted at first sight. They are, as written by Herbert (2000), both place-bound and place-making. In this sense, geography is ethnographic because it searches for the meanings behind the everyday use of space. It discloses recurrent structures and relations of power between individuals, groups and society. This firmly posits geography as the main discipline to unravel the relations between micro and macro in social sciences. This new position promotes both changes in methods and subjects. Geography becomes ethnographic in the methodological sense of the word. Qualitative methods, but more significantly participant observation, long interviews, discourse analysis, historical reconstructions are now part and parcel of the geography curriculum and of research practice. Subjects like the home as a space of social reproduction and the connected study of domestic activities, gender analysis but even further the relations between sexuality and space or the way our bodies relate to/produce space, the relation between power and spatial arrangements as expressed in Foucault's (actually Bentham's) Panopticon (1975) pop up in many recent research.

19 Time and spatial arrangements have a structuring effect on human activities. They are a main process of socialisation, embedding individuals into social structures (cf. the habitus concept of Bourdieu (1979), the structuration theory of Giddens (1984), who drew inspiration from Hägerstrand). Especially because of its relative inertia, the built environment channels the use and the symbols attached to space and constitutes in that way a social memory that imposes itself to individuals. This social significance of the built environment transforms it into «places», «locales» or «landscapes» ${ }^{9}$. Geography is thus at the heart of an important question in social sciences, the relations between individuals and society, agency and structure, micro and macro.

\section{Constructivism}

20 A more essential nature of recent research in human geography is related to a new ontological stance. Geography is constructivist. Initially developed in education, constructivism asserts that knowledge results from reflecting and giving meanings to experiences. Knowledge is not independent from the knower, and hence knowledge cannot be a matching representation of an external real world (objectivism). It is rather a «viable» organisation of an experiential world, enabling people to understand and participate in reality (von Glasersfeld, 1995). Obviously, knowledge can hardly have a common, shared content that imposes itself to all human beings. Every individual has his own view on reality. However, some views appear to make more common sense than others and closely resemble to self-evident truth (or correspondence between reality and knowledge). Also, some views organise the experiential world in such a way that they bear more promises for action that helps to solve the important global problems of this world. Thus knowledge and the language in which it is expressed are also clearly a political issue, giving more power over reality to those who can control it. This ontology paves the way to a new set of questions and problems that were considered as selfevident before. The example of scales can be taken up again: in such a perspective, scales cannot be given once and forever. They must result from experience, itself related to action. The examination of the social production of scales, their analysis as discursive and material arenas in which power relations temporarily crystallise into institutions, the 
analysis of jumping of scales in order to alter power relations within class, gender, ethnic or cultural struggles, become now evident questions, although with complex responses.

Thus a constructivist stance leads to the questioning of the processes that create geographical language and concepts and opens a new, particularly relevant realm of power and action. A similar effect is created by the «jumping of views». Much of gender geography discloses power relations that were untouched by geographers, simply because the «white, male, middle class» view is substituted by a less common and less self-evident one. Another more recent jump gave rise to postcolonial geographies (Sidaway, 2000), which deal explicitly with recovering the experiences of the colonized peoples and therefore open new avenues to understand past imperialism and hopefully to fight new forms of imperialism.

\section{Institutionalism}

22 Finally, we would say that human geography is now profoundly institutionalist. This is surely an approach with a long history and in every branch of social sciences - including human geography -, one or more institutional schools, currents or approaches have been developed. But if we highlight the institutional nature of contemporary human geography, we mean that institutions became a central concept overarching all new geographical practice. In this sense, one speaks about the «institutional turn» in geography (Wood \& Valler, 2001). Institutions are understood as norms and conventions that regulate and order social relations and practices and as such they are another side of the micro-macro relation we dealt with earlier: indeed, they are the mediating elements between everyday social practices and the reproduction of broader social structures. And precisely because they are another side of the same relation, institutions are profoundly geographical. They are part and parcel of the places, the locales and the landscape considered by present-day geography.

Especially in economic geography, the influence of the French regulation school has been significant for this institutional turn. The origins of this school can be related to the emergence of the crisis of the Fordist era and the fact that economic theories as such were unable to explain both the capacities of the economic system to sustain such a long term economic growth and the collapse of the system (Boyer, 1986). Regulation theory is precisely about institutions that embed economy in society. And geographers showed that the spatial arrangements of society are crucial in what regulationists call the modes of regulation, the set of institutions that reproduce the accumulation regimes. Harvey's spatial fix (1982) and Massey's geological metaphor (1984), although developed independently from regulation theory, capture both the inertia and the opportunities created by spatial arrangements for economic investment.

More recently, the embodiment of institutions in the conception of space is forcefully expressed in the new regional geography (Thrift, 1992) and the entrance of governance in urban and regional studies (Dostál and Saey, 2002). Although these forms of the institutionalist approach acknowledge that economic structure and state organisation shape the opportunities and values of individuals, they do not think in terms of a functional fit between modes of regulation and accumulation regimes. They rather stress the inventive way people learn collectively about the issues, interact and possibly undertake actions that react to structural or contextual pressures and thereby change that context (Healey, 1997, pp. 56, 70). 


\section{Is there progress in human geography?}

A sensible answer to this question would be to wait and see what remains from the recent developments within a few decades. However, we feel that four points can be made. The first three ones advocate progress, at least if we consider that debates and oppositions of the past now found their solution. The last point expresses a concern about the role of human geography in the present-day global world.

\section{The social nature of spatial categories}

26

$$
\begin{aligned}
& \text { progress in human geography was the theoretical and quantitative revolution. But the } \\
& \text { progress achieved in terms of theories and laws about the spatial arrangement of society } \\
& \text { was paid for by a narrow conception of space. Regularities in space that could be moulded } \\
& \text { in hypotheses and theories were found by formalising the nature of space and thus } \\
& \text { reducing it to its topological and geometrical characteristics or by generalising the spatial } \\
& \text { behaviour of human beings. As a result, what are intrinsically socio-spatial facts were } \\
& \text { emptied of their social significance. One had to wait for radical geography to reintroduce } \\
& \text { social relations into spatial categories and thus to reaffirm the importance of social } \\
& \text { power in geography, but obviously this approach could not convince the whole } \\
& \text { geographers community. }
\end{aligned}
$$

The social nature of spatial categories is now firmly established. The last uncontested

The last decades of geographical research show however that in the end, the idea that spatial categories are actually social categories is widely accepted. Again, places, locales, landscapes are seen as arenas encompassing all aspects of human action and social relations. Notwithstanding the claims of the editor cited in the introduction, this is progress. Such an approach endows geography with a much more relevant conception of reality to engage in clarifying and understanding the problems of our time.

\section{Reintroduction of the physical environment in human geographical practice}

As long as physical environment was only dealt with as an explanans of socio-spatial facts, its use in human geography encountered a taboo related to the sad role of geography in the Geopolitik and the ideology of the interwar fascist regimes. Nevertheless, today there are some signs that a new ground could be found to incorporate physical environment into human geography just like physical geography has found a new ground to incorporate the social realm into its research field. These signs all originate in the increasing ecological stress on this planet. Physical geographers are at the core of these matters but the pressure of the problems is such that they are joined by others, natural scientists as well as engineers and agronomists. Partly, the plea to introduce the social realm in physical geography is related to the competition between these disciplines to attract students, research money and to create jobs (the geographer's old ability to synthesise social and natural sciences being his best asset in this competition). However, in the wake of the new stance taken by geographers, nature is presently considered as an hybrid category, being natural and social at the same time (Latour, 1993; Cornut and Swyngedouw, 2000). Nature is not external to society and 
therefore looses its universal character. The root of this new conception can once again be found in Marxist historical materialism and its dialectics ${ }^{10}$. Social relations only exist through the transformation of the physical environment in order to respond to human needs and these relations make and transform nature just as they make and transform society ${ }^{11}$.

29 A short overview of how ecosystems have been dealt with since the sixties highlights the way covered. From the static equilibrium of the ecosystem of the Club of Rome and the urge to respect these constraints imposed by nature, the conception moved towards sustainable development, which implies a dynamic equilibrium (the concept of development would be senseless otherwise) and today the idea that ecosystems are chaotic is gaining consideration. We thus accept to live with risk and uncertainty, but at the same time it implies that humanity is part of the chaos. The planet earth is turned into a gigantic experimental laboratory of global change. And this gradually attracts more and more attention from human geography. Surely, the hybrid conception of nature is a step forward in coping with this reality. At the same time these changes in the conception of ecosystems are proof of the way social development influences the formation of concepts in the natural sciences by offering thought models that reflect societal structures and dynamics (De Frenne, 1998).

\section{The opposition between the idiographic and nomothetic approaches transcended}

30 The progress achieved by theoretical and quantitative geography underlined the idiographic character of classical geography and opposed a nomothetic approach to it. Not the study of the individual features of places, but the analysis and explanation of the regularities in space would put geography on the way of science. But today, both approaches do not appear anymore as irreconcilable points of view, but as elements of a Hegelian sequence. They are the two poles of a dialectic, which is now at the heart of geography. Actually, such a point of view is a mere echo of the four characteristics of the new elements in geographical practice and both poles appeared under other concepts in the course of the description of the holographic, ethnographic, constructivist and institutionalist nature of geography. We now look at places and space with agencies and structures in mind, we consider them as key-elements in the complex dialectic between individuals and societies, between the local and the global and both idiosyncracies and regularities dissolve when the new ontology discloses the hybrid character of the objects under study. Again, one would find it difficult to contend that overcoming an old but still pregnant opposition in geographical practice is not progress.

\section{Radical geography and the issue of social justice}

31 If human geography has made progress, a new question arises. Has the relation between geography and society changed? Or in other words, has the role and the influence of geography on social reality changed? Theoretical and quantitative geography corresponded quite well to the needs of the modern world, in creating normative and sometimes voluntaristic models of the best possible, rational organisation of space. It was a full ingredient of progress and economic growth in the postwar era. The postmodern stance has put lots of question marks around this instrumentalist view of science. 

Harvey (1999) on the possible social actions in capitalism and the existence of capitalism itself. It clarifies the difference in the way a postmodernist and a historical materialist geographer conceive of social reality. The discussion raises the question whether we should look at the world as something that can be made or remade, but in the absence of any solid ground to justify such interventions in reality (the postmodernist conundrum, Webster, 2000, p. 229), or whether we should look at social reality from the viewpoint Marx formulated as follows: «Men make their own history, but not of their own free will; not under the circumstances they themselves have chosen» (Marx, 1973, p. 146). In other words, are there limits to constructivism and if yes, what are they? reach agreement about what counts as true and about a valid scientific method. This often leads to the conclusion that the production of scientific knowledge is a process of consensus building among scientists rather than a process of discovering how nature works (Labinger and Collins, 2001). However, leaving aside the question whether in view of the perennial discussions and differences of opinions between scientists it would not be better to consider fields of conflict rather than communities of consensus (Rouse, 1996), we think it still justified to conceive of science as being an effort to discover how nature works, despite the fact that the production of scientific knowledge is a process of consensus building.

are, of course, more complicated in the case of social reality, the existence of which is dependent on knowers. Let us consider the societal space of action. This space of action is characterized by a distribution of social relations and power relations, within which human beings occupy positions that make them participate in social practices in different ways. This space of action is structured, discursively as well as materially, into a field of action by ideology and ensuing action. A Marxist conceives the space of action as a field of action of social classes. A nationalist sees a field of action of peoples or nations. A certain research tradition in economics sees a game theoretic field of action of individual and collective actors. People can be mobilized to unite into a class, a nation or another collectivity on the basis of comparable or compatible positions in the space of action, and, although a social theorist might be correct in attributing a greater probability to the formation of one particular collectivity, there is no reason to give ontological priority to this formation: the mobilizations and ensuing actions based on the other discursive structurations of the space of action may change the material structuration of that space, in other words, they may change the degree to which positions are comparable or compatible and, as a consequence, the division of probabilities (Bourdieu, 1994). This means that the future is open. Different futures are possible, i.e. realizable. Different descriptions (the discursive fields of actions) of social reality (the space of action) can thus be true at the same time and they can lead to a change in what they describe (the material fields of action). However, this does not imply that social reality would be different from physical reality in the sense that only the latter would exist and act independently of the knowledge of it. Also "[sociological mechanisms] exist and act, at any moment of time (punctually), independently of the knowledge of them» (Bhaskar 1998, p. 169). After all, there are futures that are not realizable, implying that their descriptions (discursive structurations of the space of action) are patently false.

The upshot of our argumentation is that a constructivist interpretation of the Marxist conundrum «men make their own history, but not of their own free will; not under the 
circumstances they themselves have chosen» makes more sense than the postmodern constructivist conundrum «the world can be made and remade, but it cannot be justified on any solid grounds». A crucial consequence is that radical geography, which up to now appeared as a necessary step to attain the nature of geography we described in this short essay, remains a fundamental component to human geography in order to explicit the question of social justice.

During her maiden speech at the International Geographical Union Conference in SouthKorea, newly elected president Anne Buttimer stated that the ethical mission of geography is «to explore and explicit the common interests of humanity and its planet» (2000). Radical geography is able to prove the naivety of such a statement. Its basic idea is that:

«social struggle, waged by social movements, makes human beings conscious of the fact that desirable purposes, which till then did not even belong to the imagination, are brought within reach trough the formation of new social relations. Desirable purposes refer to collective interests. Collective interests, like all sectional interests, originate in certain social positions and situations, but, in contrast with other sectional interests, they exert an attraction on other social groups. This attraction derives from the development of a comprehensive ideology. Its existence is proved through social struggle and reaches so far that members of nearly all social strata side with the movement» (Saey 1989, p. 25, referring to historical materialism).

The mission of geography should not be «to explore and explicit the common interests of humanity and its planet», because social reality is not structured in a way that there exists something that could be called «the common interests of humanity and its planet». The problem is which, or better, whose collective interests should be promoted, i.e. how should the space of action be structured.

\section{BIBLIOGRAPHY}

AMIN A. (2001), «Moving on: institutionalism in economic geography», Environment and Planning A, 33, pp. 1237-1241.

AYER A.J. (1969), Metaphysics and common sense, London, Macmillan.

BASSETT K. (1999), «Is there progress in human geography? The problem of progress in the light of recent work in the philosophy and sociology of science», Progress in Human Geography, 23, pp. 27-47.

BHASKAR R. (1998), The possibility of naturalism, a philosophical critique of the contemporary human sciences, London, Routledge, $3^{\text {rd }}$ edition.

BOURDIEU P. (1979), La distinction, Paris, Editions de Minuit.

BOURDIEU P. (1994), «Social space and symbolic power», in The Polity Reader in Social theory, Cambridge, Polity Press, pp. 111-120.

BOYER R. (1986), La théorie de la régulation, une analyse critique, Paris, La Découverte. 
BRENNER N. (2001), «The limits to scale? Methodological reflections on scalar structuration», Progress in Human Geography, 25, pp. 591-614.

BRUNET R. (1993), «Exemplaire Belgique», L’Espace géographique, 22, pp. 189-190.

BRYSON J.R , DANIELS P.W., HENRY N., POLLARD J. (eds.) (2000), Knowledge, space, economy, London/ New York, Routledge.

BUTTIMER A. (2000), «Agora for the Twenty First Century», I.G.U.Bulletin, 50, 2, pp. 377-380.

CORNUT P., SWYNGEDOUW E. (2000), «Approaching the society-nature dialectic: a plea for a geographical study of the environment», Belgian Journal of Geography, pp. 37-46.

DEAR M.J., FLUSTY S. (eds.) (2002), The space of postmodernity. Readings in human geography, Oxford, Blackwell.

DE FRENNE T. (1998), «De wedergeboorte van de natuur in de menselijke aardrijkskunde», De Aardrijkskunde, 22, pp. 15-22

DENIS J. (dir.) (1992), Géographie de la Belgique, Bruxelles, Crédit Communal

DOSTÁL P., SAEY P. (eds.) (2002), Belgian Journal of Geography,(3: issue on Governance and geography).

FOUCAULT, M. (1975), Surveiller et Punir: Naissance de la Prison, Paris, Éditions Gallimard.

GIDDENS A. (1984), The constitution of society, Cambridge, Polity Press.

GOLLEDGE R.G. (1999), «Looking back and looking forward», Geographical Analysis, 31, pp. 318-323.

HARVEY D. (1982), The limits to capital, Oxford, Blackwell.

HARVEY D. (1999), «On fatal flaws and fatal distractions», Progress in Human Geography, 23, pp. 557-563.

HEALEY P. (1997), Collaborative planning: shaping places in fragmented societies, London, Macmillan.

HENRY N., PINCH S. (2001), «Neo-Marshallian nodes, institutional thickness, and Britain's 'Motor Sport Valley': thick or thin?» Environment and Planning A, 33, pp. 1169-1183.

HERBERT S. (2000), «For ethnography», Progress in Human Geography, 24, pp. 550-564.

HUBBARD P. (2000), «Desire/disgust: mapping the moral contours of heterosexuality», Progress in Human Geography, 24, pp. 191-217.

JESSOP B. (2001), «Institutional (re)turns and the strategic-relational approach», Environment and Planning A, 33, pp. 1213-1235.

JONES A. (1999a), «Dialectics and difference: against Harvey’s dialectical 'post-Marxism'« , Progress in Human Geography, 23, pp. 529-555.

JONES A. (1999b), «Notes from the deck of the postmodern Titanic: a response to David Harvey», Progress in Human Geography, 23, pp. 563-566.

JONES M. (2001), «The rise of the regional state in economic governance: 'partnerships for prosperity’ or new scales of state power?», Environment and Planning A, 33, pp. 1185-1211.

LABINGER J.A., COLLINS H. (eds.) (2001), The one culture? A conversation about science, Chicago, University of Chicago Press.

LATOUR B. (1993), We have never been modern, New York/London, Harvester Wheatsheaf.

LAW J., HETHERINGTON K. (2000), «Materialities, spatialities, globalities», in BRYSON et al., pp. 34-49. 
MACLEOD G. (2001), «Beyond soft institutionalism: accumulation, regulation, and their geographical fixes», Environment and Planning A, 33, pp. 1145-1167.

MARSTON S.A. (2000), «The social construction of scale», Progress in Human Geography, 24, pp. 219-242.

MARSTON S.A., SMITH N. (2001), «States, scales and households: limits to scale thinking? A response to Brenner», Progress in Human Geography, 25, pp. 615-619.

MARX K. (1973), Surveys from exile: Political writings. Vol. 2,Harmondsworth, Penguin Books.

MASSEY D. (1984), Spatial divisions of labour, London, Macmillan.

RATZEL F. (1903), Die Politische Geographie oder die Geographie der Staaten, des Verkehres und des Krieges, München/Berlin, Oldenbourg, 2. Auflage.

ROUSE J. (1996), Engaging science. How to understand its practices philosophically, Ithaca/London, Cornell University Press.

SAEY P. (1989), «De zelfperceptie voorbij: ruimtelijke ordening als praktisch project. 2b. De maatschappelijke betekenis van de ruimtelijke ordening», Planologisch Nieuws, 9, pp. 97-109.

SAEY P. (1990), «De geografische studie van de samenleving», De Aardrijkskunde, 14, pp. 69-306.

SCHAEFER F.K. (1953), «Exceptionalism in geography, a methodological examination», Annals of the Association of American Geographers, 43, pp. 226-249.

SIDAWAY J.D. (2000), «Postcolonial geographies: an exploratory essay», Progress in Human Geography, 24, pp. 591-612.

SWYNGEDOUW E. (2003), «Scaled geographies. Nature, place, and the politics of scale», in MCMASTER R., SHEPPARD E. (eds.), Scale and geographic inquiry: Nature, society and method, Oxford, Blackwell (in print).

TAYLOR P. (1989), Political geography. World-economy, nation-state and locality, London, Longman.

THRIFT N. (1992), «For a new regional geography», Progress in Human geography, 15, pp. 456-465.

VERRAN H. (2001), Science and an African logic, Chicago/London, The University of Chicago Press.

VEYRET Y. (2003), «La géographie physique des vingt-cinq dernières années en France», Belgeo, 2, pp.145-156.

VON GLASERSFELD E. (1995), «A constructivist approach to teaching», in STEFFE L., GALE J. (eds.), Constructivism in education, New Jersey, Lawrence Erlbaum Associates, pp.3-16.

WEBSTER F. (2000), «Virtual culture: knowledge, identity and choice», in BRYSON et al., pp. 226-241.

WOOD A., VALLER D. (2001), «Guest editorial», Environment and Planning A, 33, pp. 1139-1144.

\section{NOTES}

1. Or rather essay. This article does not present the results of a systematic research into the tendencies in human geography since the 1980s, but expresses a personal view, gradually built up during career-long fundamental, critical and applied research on mainly location theory, social urban geography and political geography, and sustained by the reading of recent work (among which Bryson et al., 2000, or Dear and Flusty, 2002). 
2. Interestingly, in the Belgian case, this tendency towards united geography dealing with environmental problems is also imposed by the competition physical geographers face from agronomists and engineers who emphasize a stronger technical training, but cannot exhibit a comparable instruction in social sciences (physical and human geographers have a common curriculum in Belgium).

3. Ontology is about the nature of reality. Epistemology about the way to describe and understand it. The confusion lies in the fact that postmodern authors reduce reality to what is created through our descriptions, understanding and use of it. An example: Law and Hetherington (2000) suggest that distances and spaces are made, which means that they do not exist by themselves, as part of a reality totally independent of human existence. This applies not only to the sixteenth century action space of the Portuguese, but also to the geographical space of surveyors and cartographers. While it is true that geographical space appeared as a piece of reality through the work of these surveyors and cartographers and that these were working in a peculiar setting of societal conditions to do so, it remains that geographical space is not man-made. Clearly, the Portuguese action space can be undone in a way that geographical space cannot be undone.

4. The forms of postmodernism concerned share this inclination with existentialism (cf. Ayer 1969).

5. Metaphors can be terms that are applied to another object to mark telling features of that object, acquiring in this way the character of a definition. The object concerned gets a new identity. A second meaning of metaphors is that they are analogies of solely heuristic value (e.g. «universities are enterprises that produce knowledge»). Finally, metaphors are purely images conveying in a telling way a negative or positive appreciation (cf. Brunet's dinosaur). Holograpy and ethnography are metaphors in the first meaning.

6. The term «holography» is taken from Verran, who herself quotes Strathern: «[The relation] is holographic in the sense of being an example of the field it occupies, every part containing information about the whole and information about the whole being enfolded in each part" (Verran, 2001, p. 254). Holism attributes a kind of metaphysical significance to a whole. This significance is to be deduced from the way in which a researcher tries to make clear in a synthesis how the whole is greater than the sum of the parts. The whole itself eludes any analysis. Holography, on the other hand, precisely makes the whole amenable to analysis. The term «holism» is also used to refer to an approach that studies society in its totality or, looked at from the point of view of the separate social sciences, in a multi-, inter- or transdisciplinary way. It seems more appropriate to use the terms «integral» or «integrating» instead of «holistic» in these cases.

7. One could contrast the political geography of Friedrich Ratzel (1903), which led to the German Geopolitik precisely because it considered the national scale as the only important one, and the present-day political geography of Peter Taylor (1989), embedded in world system analysis, but overarching all spatial and social scales down to neighbourhoods and household structures.

8. However, the contribution of other forms of geographical study should be acknowledged: the analytical neo-behavioural geography and its interest in decisionmaking; the (pre-Giddens or pre-regulationist) institutional geography and its interest in bureaucratic structures, organisations, social institutions and relations; humanistic geography and its interest in the resilience of local communities (Saey, 1990, p. 252). 9. The latter having therefore a much broader and focussed significance, compared to the traditional concept of visual nature, possibly transformed by human action. 
10. One could argue that French possibilism and its postwar forms (e.g. Gourou's tropical geography) are equivalent forerunners of this conception.However, they stress much more the relations between human beings and their environment than social relations and consequently tend to reduce social relations to territorial ones.

11. This «jump of view» is nicely illustrated by the change in the title of one of the oldest television broadcasts on nature in Belgium. It started in the late fifties under the title Histoire naturelle («Natural history») - the concept emphasises the independent course of natural against human history -, and still exists today as Le Jardin Extraordinaire («Wonderful garden»). Difficult indeed to think of a more hybrid piece of nature than a garden.

\section{ABSTRACTS}

This paper concerns the changes in human geographical research over the last 20 years as far as the mainstream Anglo-Saxon publications are concerned. We contend that although a lot of continuity appears through the further co-existence of the three broad approaches in geography (regional, theoretical quantitative and radical), societal and scientific changes have brought new elements into geographical practice. They can be captured with four characteristics: human geography is holographic, ethnographic, constructivist and institutionalist. The two first characteristics are metaphors of the geographical empirical stance that seeks to unveil the whole within the parts and the symbolic order behind everyday practice. The two others are more essential and point to the fact that geography now explicitly examines the socio-spatial reality as a social product shaped by and reshaping human institutions. As a result geography has made a lot of progress. It uses more relevant concepts to engage in clarifying the problems of our time, the physical environment is reintroduced in human geography as a hybrid category and the old opposition between the idiographic and nomothetic approaches is finally transcended. However, there are limits to the postmodern constructivist stance, which imply that radical geography remains a crucial component of human geography in order to explicit problems of social justice.

Ce papier décrit la nature des changements en géographie humaine ces vingt dernières années en se basant essentiellement sur la littérature anglo-saxonne. Bien que beaucoup de continuité se manifeste dans le maintien de la coexistence des trois grands courants de la géographie humaine (régional, théorique-quantitatif et radical), les changements sociaux et scientifiques ont induit de nouveaux éléments dans la pratique géographique. Nous les saisissons à l'aide quatre caractéristiques: la géographie humaine est holographique, ethnographique, institutionnaliste et constructiviste. Les deux premières caractéristiques sont des métaphores du travail empirique qui cherche à découvrir les manifestations de l'ensemble dans l'analyse des parts de la réalité et l'ordre symbolique dans les pratiques quotidiennes. Les deux autres sont plus essentielles et indiquent que la géographie considère la réalité socio-spatiale comme produit social et que celleci est façonnée par des institutions humaines qui à leur tour sont façonnées par celle-ci. Il en résulte que la géographie humaine a fait beaucoup de progrès : elle utilise des concepts plus pertinents pour clarifier les enjeux de notre temps, elle réintroduit l'environnement physique en tant que catégorie hybride et elle transcende enfin la vieille opposition entre approches idiographiques et nomothétiques. Cependant nous percevons également des limites à l'approche 
constructiviste postmoderne, qui impliquent que la géographie radicale reste une composante fondamentale de la géographie humaine afin d'expliciter les problèmes de justice sociale.

INDEX

Mots-clés: géographie humaine, épistémologie, postmodernisme

Keywords: human geography, epistemology, postmodernism

\section{AUTHORS}

\section{CHRISTIAN KESTELOOT}

Catholic University of Leuven, Institute for Social and Economic Geography, Belgium, chris.kesteloot@geo.kuleuven.ac.be

\section{PIETER SAEY}

University Ghent, Department of Geography, Belgium, piet.saey@UGent.be 